\section{O-145 原発性肺癌術後再発治療：方針の変化と予後}

\author{
${ }^{1}$ 大阪市立総合医療センター 呼吸器外科, ${ }^{2}$ 東京医科大学外科第一講 \\ 座
}

中嶋 隆 ${ }^{1,2}$, 多田 弘人 ${ }^{1}$, 小田 知文 ${ }^{1}$, 福原 健次郎 ${ }^{1}$, 山本 良二 ${ }^{1}$, 加藤 治文 ${ }^{2}$

【目的】原発性肺癌術後再発症例に対する治療は現在も確立されたも のはない.しかし近年, 新規抗癌剤や分子標的薬剤の登場などで治療 の選択肢は増え，担癌で長期生存している例も散見される．今回我々 は，術後再発例治療動向の変化，予後の変化とその因子を後乃向きに 検討し, 術後再発例の治療指針の考察を行った.【方法】1993 年 12 月 〜 2002年 12 月で当施設にて完全切除を行った原発性肺癌 1182 例より, 生存解析可能な術後再発例 229 例を抽出. 1998 年以前に治療した前期 群と以降に治療した後期群に分け, 治療内容, 予後の比較を行った。

【結果】前期治療群で再発した群 152 例, 後期治療群で再発した群 76 例，患者背景は両群間に差はなかった，再発後治療内訳では全身療法 / 局所療法 / 無治療, は, 前期治療群で, 27/64/61, 後期治療群で 32/17/27であり, 全身療法施行例が有意に増加していた. KaplanMeier 法による予後解析では, 初回手術からの Disease time to progression は前 / 後期治療群の中央值は, 10.2 ヶ月/9.5 ケ月とも有 意差はなかったが, 再発後 MST は, 前期治療群で 9.1 ケ, 後期治 療群 14.9 ケ月と有意差をもって改善していた。また前期治療群では 全身療法のあるなしは，予後に有意な差を認めなかったが，後期治療 群では全身療法施行群で有意に予後が延長していた.【結語】近年の術 後再発患者の予後は, 改善している，全身療法である化学療法施行例 の増加がその因子となっており, 術後再発時の積極的な全身療法の施 行 / 併用で予後が改善する可能性が示唆された.

\section{$0-147$}

\section{大腸癌肺転移切除例の成績と予後因子の検討}

東京都立駒迟病院 呼吸器外科

堀尾 裕俊, 坂口 幸治, 桑原 克之

【目的】大腸癌肺転移症例に対する外科治療成績を検討した。【対象と 方法】 1998 年 4 月より 2002 年 12 月までに肺切除を行った 91 例を対 象. 生存率は Kaplan-Meier 法で算出, 予後因子は単変量および多変量 解析した．統計学的有意差検定は $\mathrm{p}<0.05$ で有意差ありとした.【成 績】男性 62 例，女性 29 例. 平均年齢は $58.8 \pm 11.7$ （22-84）歳. 原 発部位は盲腸 2 例, 上行 12 例, 横行 4 例, 下行 3 例, S 状 23 例, 直 腸 47 例. 原発切除時肺転移存在 8 例, 初回肺切除時多発転移 49 例, 初回肺切除までの平均期間 $38.9 \pm 27.2(0-137)$ か月，術前 CEA 高 值 $(\geqq 5 \mathrm{ng} / \mathrm{ml}) 48$ 例, 転移腫瘍平均径 $3.1 \pm 1.8(0.5-9.0) \mathrm{cm}$, 術 式は区切以下 59 例，葉切 32 例，平均肺切除手術回数 $1.3 \pm 0.6$ (14) 回, 肝転移切除 40 例, 肺切除前化学療法既往 61 例. 全体の 5 生率, 10 生率はそれぞれ $29.0 \%, 16.1 \%$ 。単変量解析での予後不良因子は原 発切除時肺転移存在 $(p=0.0092)$, 多発肺転移 $(p=0.0136)$, 肝転 移切除 $(\mathrm{p}=0.0007)$, 術前 CEA 高値 $(\mathrm{p}=0.0459)$, 肺所属リンパ 節転移陽性 $(p=0.0094)$, 肺転移非完全切除 $(p=0.0065)$ であっ た. 性別, 年齢, 原発部位, 肺切除までの期間, 転移腫瘍径, 肺切除 回数, 術式, 肺術前化学療法は相関がなかった．多变量解析では単変 量解析で指摘されたCEA高值例を除く，すべてが独立した予後因子で あった。【結語】大腸癌肺転移症例に扔ける予後不良因子は原発切除時 の同時肺転移存在, 肝転移存在, 多発肺転移, 肺所属リンパ節転移陽 性，肺転移の非完全切除であった，完全切除が見达まれれば区域切除 以下で十分と考えられた。
O-146 骨肉腫切除後の胸壁および肺転移に対する外科

${ }^{1}$ 大阪市立大学 医学部 呼吸器外科, ${ }^{2}$ 大阪市立大学 医学部 心臟 血管外科

水口 真二郎 ${ }^{1}$, 井上 清俊 ${ }^{1}$, 岩田 隆 ${ }^{1}$, 泉 信博 ${ }^{1}$, 月岡 卓馬 ${ }^{1}$, 森田 隆平 ${ }^{1}$, 末廣 茂文 ${ }^{2}$

【目的】骨肉腫肺転移は可及的肺切除により予後が改善することが知 られている。肺切除時に胸壁合併切除を要する症例も少なくなく，そ の意義を明らかする。【対象・方法】肺切除を施行した原発巣切除後の 骨肉腫肺転移 30 症例を対象とした。このうち7例に胸壁合併切除を施 行したが，この 7 例全例の無病悩期間（DFI）は90日以上であった. そこで肺転移群を早期肺転移群 $($ DFI $<90)$ および後期肺転移群 (DFI ミ90)にわけ，臨床病理学的進展因子と切除成績の関連を単变量解析 および多変量解析を用いて胸壁合併切除の有用性を検討した。【結果】 年齢, 性別, 肺転移巣切除術式, Tumor doubling time には各群間に有 意差は認めなかった。早期肺転移群 6 例と後期肺転移群 17 例の 5 年生 存率はそれぞれ $0 \%$ および $32 \% て ゙ あ り ，$ 早期肺転移は有意に予後不良

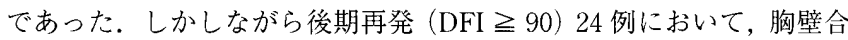
併切除施行例 7 例と非施行例 17 例の 5 年生存率はそれぞれ $18 \%$ と $32 \%$ であり，有意差を認めなかった。単変量解析に执いて転移個数 5 個以 上およびDFI90 日以下症例は有意に切除成績が不良であった。多变量 解析でも転移個数 5 個以上扮よびDFI90 日以下が独立した予後不良因 子であり，それぞれの相対危険度は $4.9(\mathrm{P}=0.013)$ および $5.4(\mathrm{P}$ $=0.006)$ であった. 胸壁合併切除の相対危険度は $1.4(\mathrm{P}=0.601)$ であり独立した予後不良因子ではなかった、【まとめ】胸壁転移を伴う 肺転移症例であっても無病悩期間が 90 日以上であれば積極的な外科 治療の有用性が示唆された。

\section{O-148}

${ }^{1}$ 北海道大学, ${ }^{2}$ 北海道大学 核医学講座

大竹 節之 ${ }^{1}$, 森川 利昭 ${ }^{1}$, 石川 慶大 ${ }^{1}$, 東海林 安人 ${ }^{1}$,

中島 誠一郎 ${ }^{1}$, 平野 聡 ${ }^{1}$, 近藤 哲 ${ }^{1}$, 玉木 長良 ${ }^{2}$, 竹井 俊樹 ${ }^{2}$

(目的) PET 検查は悪性腫瘍の遠隔転移の診断に有用であると言われ ている。しかしその感度や原発臓器による差違についてはあきらかで はない，当院での転移性肺癌に対するFDG-PETの成績について検討 した。 (対象) 当科にて組織学的に転移性肺癌と診断され, 術前 PET が施行された 28 例 32 病変. 原発臓器別では大腸癌 7 例, 腎癌 4 例, 子宮癌 3 例, 食道癌, 卵巣癌各 2 例で, 他は全て 1 例で頭垢部領域が 5 例, 胆膵領域 4 例, 肺癌が 1 例であった（方法）使用機器はシーメ ンス社製 ECAT。病変に対する視覚的評価で集積の有無を判断した。

(結果) 全病変中集積を認めたのは 23 病変で感度は $71.9 \%$ 市った. 原発臓器別では大腸癌が $77.8 \%$, 子宮癌 $66.7 \%$, 腎癌 $40.0 \%$ あった。 頭䅡部領域癌は $80 \%$, 胆膵領域癌は $75.0 \%$ あった。組織型別の感度 は扁平上皮癌が $71.4 \%$, 腺癌が $73.7 \%$ で有意差を認めなかった，集積 を認めた病変の大きさは平均 $19.7 \mathrm{~mm}$, 集積を認めなかった病変の大 きさは平均 $12.5 \mathrm{~mm}$ であった $(\mathrm{p}=0.01)$. 28 例のうち原発巣にもPET が施行されていた症例は 4 例でいずれも原発巣の集積の有無と転移巣 の集積の有無は一致していた，集積を認めなかった 8 例のうち，原発 巣にも集積を認めていない症例が 1 例, 腫瘍が横隔膜直上に存在して いた症例が 1 例, 術前に化学療法を施行していた症例が 3 例, 原発巣 の術後に化学療法を施行していた症例が 1 例であった。化学療法が施 行されておらず組織学的に壊死を認めた症例が 1 例であった。また術 前化学療法を施行していた 5 例中 3 例に集積を認めなかった。(結語) 転移性肺癌に対する FDG-PET の感度は $71.9 \%$ で, 術前に化学潦法を 施行されている症例や腫瘍の大きさに影響されると思われた。 